\title{
UCLPRESS
}

International Journal of Social Pedagogy

\section{Social Pedagogy: An Approach Without Fixed Recipes}

Jan Jaap Rothuizen ${ }^{1, *}$, Lotte Junker Harbo ${ }^{1}$

How to cite: Rothuizen, J.J., Harbo, L.J. 'Social Pedagogy: An Approach Without Fixed Recipes.' International Journal of Social Pedagogy, 2017, 6 (1), pp.6-28. DOI: https://doi.org/10.14324/111.444.ijsp.2017.v6.1.002

Published: 6 October, 2017

\section{Peer Review:}

This article was originally published in RES, Revista de Educación Social, 19 (2014), under the Creative Commons Attribution International License (CC-BY) and can be accessed here:

http://www.eduso.net/res/19/articulo/educacion-social-entre-la-vida-cotidiana-y-la-profesion

\section{Copyright:}

(C) 2017, The Author(s) - This is an Open Access article distributed under the terms of the Creative Commons Attribution License (CC-BY) 4.0 https://creativecommons.org/licenses/by/4.0/, which permits unrestricted use, distribution and reproduction in any medium, provided the original author and source are credited • DOI: https://doi.org/10.14324/111.444.ijsp.2017.v6.1.002

\section{Open Access:}

International Journal of Social Pedagogy is a peer-reviewed open access journal. 


\title{
Social Pedagogy: An Approach Without Fixed Recipes
}

\author{
Jan Jaap Rothuizen
}

Lotte Junker Harbo

\begin{abstract}
A historical and theoretical reconstruction of the specificity and peculiarity of the discipline of social pedagogy, as it has developed in Denmark. Social pedagogy takes its departure from the idea that the individual person and the community are complementary but at the same time opposed to each other, so the task of social pedagogy is rebalancing the dynamics between the two. Social pedagogy is also characterised as a discipline with three dimensions: a practical dimension, a theoretical dimension and a professional dimension. The professional's task is neither to apply theory in practice nor to uphold the usual practice; it is to mediate between theory and practice. The specificity of the discipline gives rise to particular challenges and dilemmas that theorists make understandable and transparent and practitioners have to deal with. A big challenge for social pedagogy is the quest for evidence-based methods that overrides the specificity of the social pedagogical approach. Balancing different forms of knowledge implies that programmes and methods are used as inspiration that can be contained in a social pedagogical approach.
\end{abstract}

\section{Keywords}

democratisation; participation; social inclusion; social pedagogy; well-being; pedagogical relationship; professionalism 
The term social pedagogy can have different meanings, so we start this article by exploring some of its history to contextualise and help understanding of our discussion of social pedagogy first and foremost as an approach that focuses on the other person's possibilities to decide, to act and be active, and to participate. When practising a social pedagogical approach, one will often find oneself in situations where there is no fixed recipe for what to do because social pedagogy occurs in a variety of tension fields described in the article. Following this, we show how social pedagogical work, happening in the everyday life and reliant on the applied professionalism of the practitioner, is in constant development. Finally we point out the challenges we see in relation to sustaining the understanding of social pedagogy illustrated in the article.

\section{Roots of Social Pedagogy}

The term social pedagogy is first used in Germany by Karl Mager (1810-58) and Adolph Diesterweg (1790-1866) around 1850. German society, at this point, was experiencing extensive social, political, economic and cultural changes due, at least in part, to how different regions were organised, growing awareness of the wide-ranging effects of poverty and to the emergence of industrialisation; 'social pedagogy' is thought of as pedagogy's contribution to the development of a unified German society (Konrad, 2009). Mager linked social pedagogy to democratisation: the framework for the upbringing and education (pedagogy) of and for citizens who participate as free persons in social, cultural and political life. Today in Denmark, the concept of civic education is used in this sense. Diesterweg used social pedagogy as a framework for the pedagogical tasks that could contribute solutions to the social and pedagogical problems that appeared in the modern, emerging industrial society. Mager's concept of social pedagogy applies to everyone, while Diesterweg's concept applies to particular groups, at risk or of experiencing marginalisation, who could benefit from social pedagogical efforts. However, common to both perceptions is that they understand the human (child and adult) as a social being who participates in social activities, and that therefore social pedagogy is concerned not only with the individual and their social connections, but also with developing a connected, productive society, relevant for the modern age. 


\section{Danish Social Pedagogy}

In Denmark, no particular attention was given to the theoretical discussions about social pedagogy at that time. Instead the concept of reform pedagogy was a landmark. ${ }^{1}$ Reform pedagogy stresses individual flourishing and strives to reform social aspects: practices and approaches were developed particularly in connection with the creation of daycare institutions (Erlandsen \& Kornbeck, 2004). In this process of establishing daycare institutions we find an emerging understanding of social pedagogy that emphasises compensating for bad social conditions and stimulating rewarding social relations (Tuft, 2009). Breaking away from authoritarian pedagogy that sought to create a one-sided view of 'good' or 'productive' citizens, reform pedagogy was child-centred.

\section{The importance of participation and integration}

Between 1960 and 1980, the term social pedagogy gained a footing but this time in connection with particular precautionary measures. Work with marginalised children and youngsters placed outside the home took a turn around 1960 to become based on a personality categorisation of children. Thus, there were 15 different types of children's homes based on a psychological and individualising categorisation. In the 1960s and 1970s this approach and practice began to compete with alternatives to traditional social pedagogical residential care such as social pedagogical 'ship-projects' and 'work and living communities' or 'cohabitation-communities' (Aude \& Bundesen, 2003). Both the ship-projects and the work-and-living communities are based on living and working together in a little community (on a ship or, typically at that time, in a former farmhouse), where every person is needed, has duties, has a role and a value (see also Hegland, 1994). They are not seen as objects for treatment, but as active participants. ${ }^{2}$ Simultaneously, there was an ongoing development in the special care sector which, in 1981, led to a transition from state-organised care in asylums, to care organised and financed by local authorities. The big central institutions were shut down, and a care-oriented approach was replaced by a social pedagogical approach. The term social pedagogy thus signals integration; that one supports the young or the disabled in order for them to become part of their society. Welfare and care work became pedagogical. The pedagogical aspect consisted, to a large degree, of marginalised adolescents or disabled people 
being offered an everyday life where they experience themselves as participants.

In 1983, the education (a) for employees in 24-hour care institutions for children and adolescents, (b) for employees in the special care sector, i.e. for disabled children, and (c) in general for employees seeking to help people who were in danger of becoming or were marginalised were consolidated and renamed 'Social Pedagogical Education'. This is also where employees for nurseries are trained, which is often substantiated with the understanding that students must have a thorough understanding of 'normal development', which will be explored later in the article. Historically, it can be further explained with the consideration that the daycare institutions for toddlers were originally created to prevent poor social conditions from depriving children of a good childhood, and to promote children's participation in the societal community. In these institutions a social problem was addressed by giving children space to be participants in a human community.

\section{Danish social pedagogy today}

Turning to the present, in the Organisation for Economic Cooperation and Development (OECD)'s programme 'Starting Strong: Early Childhood Education and Care' $(2001,2006)$ two orientations in early childhood education are identified: the 'pre-primary' and the 'socialpedagogy' approaches. In the social pedagogical approaches, early childhood services

retain a strong identity distinct from the school; social pedagogy treats care, upbringing and education as an inseparable whole and places importance on work with the whole child, broad developmental goals, interactivity with peers and educators and quality of life; and it seeks a balance between culturally-valued topics of learning (such as, music, song, dance, environmental themes) and supporting the child's meaning-making acquired through relationships and experience of the world. (Moss, 2007, p. 18)

Today, in Denmark social pedagogy is often identified as the field of work where the employees are organised in the trade union called 'The Social Pedagogues'. These people work with marginalised chilren, adolescents and adults in 24-hour care institutions, on the street, in the community psychiatry, in relation to people with learning disabilities, addicts and homeless people. 
Social pedagogy is concerned theoretically with new forms of marginalisation, and practically with efforts that aim towards integration, inclusion and citizenship. For example, Søren Langager, leader of a research programme in social pedagogy at Aarhus University, has published a case study about young people at risk which shows how theoretical sociological analyses can inspire the development of new practical social pedagogical work methods (Langager, 2009). Also in the field of early-childhood education we find social-pedagogical approaches, both in the sense of inclusive pedagogy and in the sense of pedagogy, that aim for greater/more meaningful participation in society by helping children develop confidence and/or other emotional, practical and social skills.

Social pedagogy is characterised by diversity as a result of its history (Kornbeck \& Rosendahl Jensen, 2009). In this sense, social pedagogy has developed with different inflections, both within the Danish borders and in other parts of Europe. Over many years, the Finnish professor in social work and social pedagogy Juha Hämäläinen has focused on social pedagogy in a comparative and international perspective. He gives an overview of how the field is both diverse and coherent:

Historically, two main developmental lines of social pedagogical thought can be identified. On one hand, social pedagogy deals with the problem of social exclusion by aiming to improve social inclusion and the welfare of those who are at risk of becoming excluded. On the other hand, social pedagogy aims to contribute to active citizenship in terms of citizenship education. In addition to these two fields of interests, the provision of care to vulnerable members of society could be mentioned as a third area connecting especially to the line of preventing social exclusion in theory and practice. Care for vulnerable adults and children, as a special area of interest of social pedagogy, aims to contribute to welfare through education. (Hämäläinen, 2012, p. 5)

In this sense, Danish social pedagogues in their work pay attention to developing internal and external qualities, processes, experiences and understandings about participation, seeing them as inherently valuable pursuits in themselves for the individuals and groups involved. In addition to this, social pedagogy as a profession, and a component of socio-political understanding that informs policy to some extent, conceptualises participation as integral to developing a 'good' society, relevant for the modern age. 


\section{Social Pedagogy as an Approach and Concept}

\section{Meaningful belonging}

Social pedagogy cannot be defined by referring to a particular target group or to a certain method. Social pedagogy is, to a larger degree, a view and an approach that has its roots in some very central insights and problems that emerged in the Western European cultural circle. Already in the seventeenth/eighteenth century, philosophers John Locke (1632-1704) (in England) and Jean Jacques Rousseau (1712-79) (in France) argued that the child has unique and extraordinary possibilities and potential and that predetermining his or her future would stifle these possibilities and potential. This type of thinking was new and radical in this period - up until this time, commonly referred to as the Age of Reason, each individual's place in society was predetermined within a fixed social order. In the modern era the relationship between the individual and society - or the community - becomes unstable.

One cannot deny that children grow up in social contexts as participants and that this, to a greater or lesser extent, leaves a trace. However, the individual also has an opportunity to influence the social context/community. It is within this unstable relationship, between the individual and community, that social pedagogy originated, testing the above as either claims or norms. The community in which the child is growing up should not be an oppressive community and the individual should have the possibility to influence it. Therefore, social pedagogy contains both a theory on socialisation and on individualisation. The idea of meaningful belonging connects the two.

The social pedagogical approach is closely or familiarly connected with, or influenced by other contemporary academic movements. For example, with symbolic interactionism and pragmatism that have roots in the so-called Chicago School, which both the social psychologist George Herbert Mead (1863-1931) and the philosopher and educational reformer John Dewey (1859-1952) belonged to in the 1920 s and 1930s. Another example of this close or familial connection is psycho-dynamic developmental psychology, developed by Erik Erikson in the 1950s, and later by Daniel Stern in the 1980s, just as there is a link to some political movements committed to democracy, liberty and equality. The Social Pedagogical approach is linked to academic and political movements that stress the importance of the interdependency of social inclusion and community development on one hand, and 
individual rights and well-being on the other. In this light, it is logical that the United Nations conventions, for example, the Convention on the Rights of Persons with Disabilities, serve as a basis for and support social pedagogical approaches.

\section{Head, heart and hands}

How is the interaction between the individual and the material and social world created? Pestalozzi (1746-1826), a Swiss pedagogue and educational reformer, inspired by Rousseau and others, answered this question by arguing that there are three dimensions involved in education - the head, heart and hands. We explain this further thus: with the head, we acquire knowledge about the world, and can create or identify connections between different sources and/or types of knowledge from a distance; with the heart, facing the world activates feelings; and with our hands, we act and process the world, further exploring knowledge and feelings. The task of the pedagogue in upbringing thus becomes to facilitate dialogue between the material and social world on one side, and the child on the other, and to assist the child in meeting, making meanings about and dealing with the resistance of the world (Biesta, 2012). The holistic approach of the head, heart and hands must work in harmony with the core values of the pedagogue, which we think are best described by the Polish children's author, pediatrician, director of an orphanage and pedagogue, Janusz Korczak (1878-1942): 'If you want to be a pedagogue you have to learn to talk with children instead of to them. You have to learn to trust their capabilities and possibilities' (Eichsteller, 2009, p. 377).

\section{The practitioner mediates between theory and practice}

Because the child's own activity is fundamental, the relationship between theory and practice in social pedagogy is almost as unstable as the relationship between the individual and the community. Imagine a situation where practice serves as a foundation for theory. In this case theory becomes an account of what already is there and the consequence would be that theory reproduces practice. Also, imagine a situation where theory serves as a foundation for practice, in this case, practice occurs as an application of theory. Whereas in natural science one can have such a relationship between theory and practice where theory explains practice and subsequently, through theory, one can master practice, in social pedagogy there are profound but subtle 
differences. In a social-pedagogical approach there must be room for the child, and the adult, to be created when facing the world. It means that something new and not previously seen in practice appears. The pedagogue must provide space for and engage in interaction with the new. Here, we describe a difference between theory and practice which means that the pedagogue as a person must mediate between theory and practice and thereby becomes responsible for the mediation between theory and practice. Social pedagogy does not oppose theory, it draws from a wide range of theory, but it does oppose the use of methods that remove focus from the living interaction between pedagogue and child. Therefore, the 'pedagogical relationship' or the 'relation' is often referred to as the focal point of social pedagogy. ${ }^{3}$ Thus, in the social pedagogical approach there are some concepts that keep returning and that therefore work as landmarks or bearings concepts such as the individual, autonomy, democracy and relationship. This is both in relation to children and to the social pedagogical work with marginalised adults.

An example: The boy with the yellow cap It was in the spring. He was a little, quiet, happy boy in the day-care institution. He was five years old. And he had a new cap, he was very fond of. This fine, colorful cap became part of him. He was reluctant to take it off. One would think that he slept with it at night. I do not know how it worked out, but it was as if the cap caused him to grow. His face was as radiant as the sun in early spring, and I have no doubt that the cap in some way helped to strengthen his identity.

One day we had been out all morning and I had good contact with him. When we came in for lunch, it occurred to me that the boy had a problem. Here in the country, the fact is that we commonly take the headgear off when we eat. That's also what we do in kindergarten. It is no problem. That's just how it is. But when I saw the boy, I got a strong feeling that he preferred to keep his hat on, just this day.

We did not talk about it, but I responded to his pleading eyes with an appreciative twinkle in my eyes and a slight nod. It was alright that he, that day, kept his fine cap on his head. Hardly any of the other children notices that a rule had been violated/broken. Both the boy and the other children were eager to get some food. There was a really good atmosphere at the table. We were already looking forward to get out in the sun again. 
But then Inger entered the room. Inger is our pedagogical assistant, she has not been in the kindergarten for so long, and she is not so flexible and bound to comply with rules. Without a word, she walked over and took the cap off the boy's head. She did not sense that the boy was upset. I could see how clouds were gathered in his previously so happy spring-face, the corners of his mouth fell, and he looked at me, appealing.

We finished the lunch-break. Both the boy and I had our good mood ruined. It was as if the sun outside no longer entered the room. (Mors, 2008, p. 44)

In this example the pedagogue accepts that the connection between the boy and his community is not stable: there is room for a certain deviance, as long as this deviance makes sense for the individual and contributes to the quality of the community or at least does no harm to the community. The pedagogue facilitates the dialogue between the child and the world, by not only using her head but also her heart. The pedagogue is both concerned with the well-being of the boy right now, and with the question of what it means to live in a community. In her acting she expresses pedagogical ideals concerning how to practise community development. The pedagogue makes a choice - there is no necessity in her attitude towards and communication with the boy, neither a practical necessity nor a theoretical necessity. She chooses to recognise the boy in his interpretation of the situation. That is illustrated by the fact that a colleague chooses another reaction. Different reactions mirror different sensibilities and different ideals concerning the relation between individual and community. This line of thinking is furthermore illustrated by a few examples from a home for people diagnosed with dementia.

A resident picked up all sorts from the street to 'decorate' her home, and one time she found a dead bird which she also collected as decoration. The pedagogue thought to give her a 'decorating bag' with lots of little objects: figurines, beautiful cards, necklaces that could be found, sorted, exhibited and moved around. Other times the pedagogue would just interpret the other's behaviour as meaningful rather than a symptom of the illness. For example, when Mr Hansen in the common room shouts 'am I dressed?' or 'where am I?' it is not because he is 'a shouter', ${ }^{4}$ but because he is disoriented. (Longer version can be found in Dybro, 2009) 
Yet again we see how the pedagogue has a choice in her actions and we see how these choices have an important impact on her perception of the people she works with.

In the Danish social legislation (Consolidation Act on Social Services, http://www.english.sm.dk/legislation), there is a paragraph concerning the care and social work in relation to adults that limits the use of forcible measures, and other restrictions of the right to autonomy, to the bare minimum (\$124). It states 'such restrictions should never be used as substitutes for care, attention or socio-pedagogical assistance'. In extension to this paragraph, the following question has been asked: can a social pedagogical approach prevent the use of force? The question was particularly relevant in relation to elderly people with dementia because many places experienced difficulty in providing care without the use of force, for example, when the demented citizen had to be washed or when she wanted to go out on her own. The right to autonomy is upheld in the Danish constitution (§71) and also in the European Declaration of Human Rights (art. 8). If autonomy means that you are a person who wishes to act meaningfully, then the first task of the social pedagogue is to find out what makes sense to the person. Instead of doing something for the person 'for her own good' which does not make sense to the person and therefore is experienced as a violation, the pedagogue seeks to create situations in which the other person can use his or her sense of judgement and act meaningfully. Sometimes this entails that the pedagogue must use his or her imagination to create situations which are foreseeable to the extent that the other person can find him or herself in it and act sensibly, regardless of his or her disability, as the pedagogue illustrates with the 'decorator bag'. By creating these kinds of situations and opportunities a community between the care-worker and the person(s) who need care is established.

\section{Focus on competent citizens}

The pedagogue creates situations in which the other person can act meaningfully. It is only possible when the pedagogue is part of a relationship, is looking for meaning, respects the right to autonomy and offers community. The pedagogue sees the other person, not as a bearer of symptoms, but as a participant who has the right to an everyday life with autonomy and community. Thereby, the pedagogue also becomes a participant in this everyday life, whether in early childhood education, care for people with dementia, pedagogical 
work with learning disabled or community psychiatry. People with disabilities, no matter how profound, are not viewed as 'objects' of charity, medical treatment and social protection, but rather as 'subjects' with rights, who are capable of claiming those rights and making decisions for their lives based on their free and informed consent, as well as being active members of society. This view of the person aligns with the UN Convention on the Rights of Persons with Disabilities (United Nations, 2006), offers a starting point for practice, is gaining territory in the field of psychiatry and is known as 'recovery orientation'. It has its point of origin in that the individual citizen is able to point out what is meaningful to him. Both with regards to the human aspect and to the effect of the treatment, it is more fruitful to relate to this than to view the citizen as an object for treatment (Shepherd et al., 2008; Slade \& Longden, 2015).

What is of great significance is that the citizen is perceived as competent. One of the patients in the psychiatric hospital in Aarhus took a new name, Ovartaci. First, it was thought that it was a symptom of his schizophrenia, but later through reflection it was discovered that the patient, through his name, was able to participate meaningfully in the everyday life in the hospital. He thought that when there was a chief psychiatrist (overlæge in Danish), there should also be a chief madman. The Danish word for chief madman is overtosse, and when you pronounce Ovartaci, this is exactly the word you can hear. ${ }^{5}$ His new name empowered him, gave him a way of participating more meaningfully, demonstrated his understanding of the world and his place within it, and all might well have been ignored, or devalued, had it been seen merely as a symptom of his diagnosis.

\section{Tension Fields}

The work of the social pedagogue does not solely consist of her carrying out certain actions. Because her work takes place in tension fields in which she must navigate, she constantly has to think and consider. In tension fields, there is something that pulls one way and something that pulls the other way. If you walk to one side, it will pull more from the other. Therefore, it is not about choosing sides but about moving within the tension field. Below, some of the significant tension fields are mentioned. 


\section{Individual-Community}

The two cannot exist without one another, but they can also get in the way of one another. If you are too much yourself it can be hard to be part of a community, and if you adapt too much to a community it can be difficult to remember who you are. I have described the fundamental dynamics in the social pedagogical work in Figure 1 below (Rothuizen, 2008, 2013).

The model must be read outwards from the inside and from the outside in. First, there is the circle between social integration and personal integrity. Often, people who need social pedagogical support know the negative, vicious circle, where an insufficient social integration and an injured integrity reinforce one another. The social pedagogical task is to turn this situation around so that self-confidence, self-respect and self-esteem (Honneth, 1996) are reinforced by a sense of belonging and participation (social integration) that becomes possible because of the increased personal integrity and vice versa. For this purpose, the pedagogue has two available means: she can enter into an inclusive relationship, where there is room, both for her and the other person, to experience a community and for them to be themselves (inclusive relationship); and she can also work towards trying to get other activities and groups in society to include the other person (inclusive environment). Social pedagogy, therefore, is about both bonding and bridging. This then leads to the next tension field.

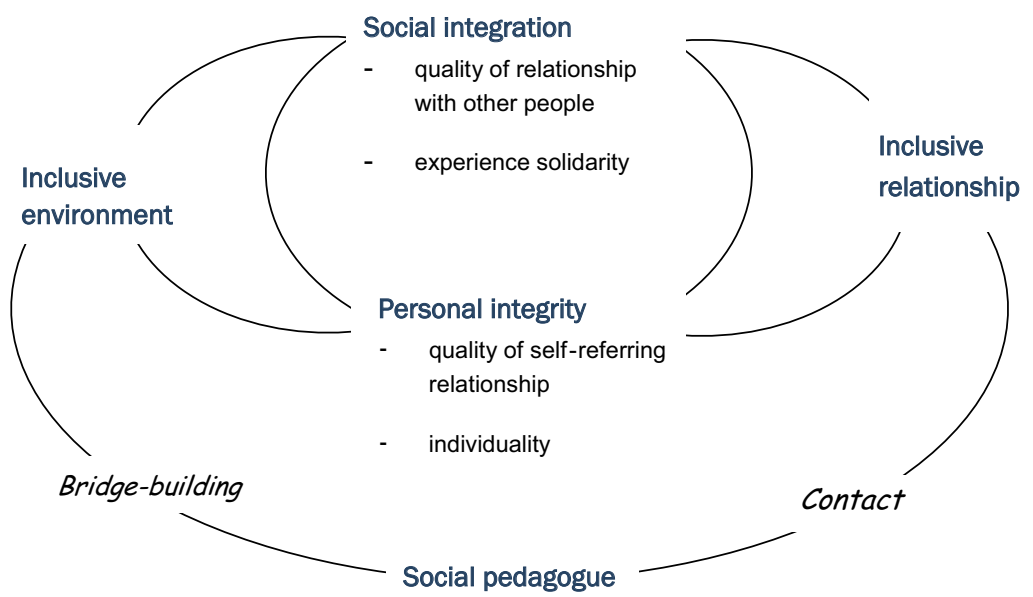

Figure 1 The task of pedagogue: turning the negative cycle by means of contact and bridge-building 
My calling - my work

In Emile Durkheim's classic text on professional ethics the French 'profession' is translated 'calling'. Nowadays the normative dimension in professional work does not play the same prominent role, as professional work often is defined as the production of certain outcomes: just work. But when one is engaged in a social pedagogical approach the task can seem so extensive that it can hardly be contained within a regular job. Perhaps one wishes to spend more time, but does not have any more time. How can you regulate your time as a professional with regards to both bridge-building (bridging) and relating (bonding)?

Often, social pedagogues report that they - in their opinion experience a lack of time for the bridge-building function. Bridgebuilding means changing society and not just working with care but also with community development, so as to address the wider and systemic aspects that affect marginalised groups. This is also required by the UN Convention on the Rights of Persons with Disabilities. Since the 1980s, social pedagogy has also been concerned with the 'opposite integration' line of thought, in which rather than marginalised people living in general society with all its obstacles, the general population takes part in a living environment specifically for the marginalised. Examples include the cohabitation community Hertha (http://www.hertha.dk/), where non-disabled people live in close neighbourliness with adult people with disabilities, and a planned Large Village (Storlandsby) for homeless and non-homeless people (http://tinyurl.com/bd856fh). In addition to the question of bridge-building, there is also the question of the inclusive relation: you want to get involved, but you also need a more professional distance which calls for a very refined sense of the relationship between the citizen and the social pedagogue. The cohabitation communities, just like the work and cohabitation communities for marginalised adolescents in the 1970s, solve the dilemma of not dividing life quite so rigidly into work and privacy. All social pedagogues involve themselves personally and they must find a balance between the personal involvement and the professional task.

\section{Knowledge and non-knowledge}

It is important to be well-informed, and to have knowledge about social exclusion, about the different problems that the citizens you work with can have, about the experiences others have had in similar work, about communication, etc. However, knowledge alone will not 
do it. If knowledge alone could do it, you would be able to 'figure out' what it took to realise goals. You could develop methods, and the only thing you would need was an employee who could use the method. In the hunt for efficiency, politicians and bureaucrats ask 'what works' and they imagine there are efforts that can be prescribed just like medicine. In the social pedagogical line of thought, it is always a case of collaboration between the pedagogue and the persons she is working with. There is always a chance that the other person is different from what you anticipated; there is even a wish that the other person will appear as a subject. Therefore, you do not put your confidence in 'what works', rather you constantly have to ask yourself: are we on the right path? Should we be doing something else? You have to ask yourself and others involved questions that encourage wider understanding of the person/people involved, the different contexts at play, exploration of assumptions underpinning thought, planning and action, imaginative speculation for other possibilities, etc. These are not questions that can be answered with actual knowledge but only with considerations of what is the right thing to do in the situation (see Bondi et al., 2011; Rothuizen, 2008; Eichsteller \& Holthoff, 2011). Social pedagogues act without being able to know beforehand whether they are doing the right thing. Therefore, it is important for them to have ethical orientation points and landmarks, to be in constant professional dialogue with colleagues and to expose themselves and each other to criticism (see Banks \& Nøhr, 2003).

\section{Profession and person}

When not just knowledge but also relation and interaction make up the everyday professional work, you cannot ignore the fact that you are also taking your personality to work. You are a professional. It matters who is working and what works for one person will not necessarily work for the other. You also have to know what it takes, but that does not mean you are always able to do what it takes. You can know that you must be more patient, but in practice you are not able to hide your impatience. Therefore, as a professional, you must also work with your own virtues and qualities.

Because the work is also personal, sometimes there is a tendency to make it very personal: 'I do it this way because that is the way I'm doing it.' This, however, eliminates professional dialogue and considerations of professional development. Authorities that face this personalised professionalism may react by calling for standards, documentation 
and methods. These can provide some guidance but are interpreted by the individual and do not answer the question of what to do in any particular moment. Therefore, the employees must find ways in which to articulate what is good to do and what is not so good to do without making it a question of whether or not the acting person is good enough. Working with narratives (Erstad, 2008) and core quadrants (Ofman, 2001) might be useful. All in all, the strongly ethical orientation of Social Pedagogy guides the professional to reflect before, in and on action, using theories, concepts and methods as guides to child/person-centred practice.

\section{Institution and citizen}

Historically, in the work with marginalised children, adolescents and adults there is a dynamic between institutionalisation and de-institutionalisation. The initiatives to take care of the marginalised were typically made by circles in the civil society during the second half of the nineteenth century. Homes were established. In the first part of the twentieth century care was institutionalised through legislation. In Denmark the first child legislation was enacted in 1905. The marginalised on one hand had their rights promoted and were protected which improved their position while, on the other hand, they became also subjected to an institutionalised system. In his work Asylums from 1961, Erving Gofman showed how stigmatisation and institutional order have a strong tendency to deprive human beings of their identity, just as Foucault showed how articulation of certain phenomena is part of a productive power and truth process in which people are subjectified in very specific ways, e.g. in his work Discipline and Punish (1995). The social pedagogical approach opposes such processes but it is subject to the same processes. One can perceive the anti-psychiatry of the 1970s as a de-institutionalisation movement which had a great impact. Even so, in the twenty-first century there is still a need for a de-institutionalisation - now conceptualised/ discussed as a recovery discourse in relation to psychiatric institutions. However much the recovery discourse is absorbed in the institutions, and influences how they are organised and transformed, it cannot rid them of some of their institutionalised characteristics. There is now a noticeable change in the discourse, from medicalised language and concepts, that described people with mental health problems or disabilities as patients, sick people needing treatment, and the judgemental language of deviants needing to be controlled, to the current language 
and conceptualisations of citizens with civil rights, which represents aspects of de-institutionalisation.

When you offer these citizens a choice between efficient and evidence-based methods that work specifically in relation to their situation, you re-install an institutionalisation. In Denmark in the 1980s, the special care sector was placed under the local authorities, which led to the closing of the central institutions and integration of cohabitations, half-way houses and smaller units in the general society. In 1998, the term 'institution' was eliminated so that all adults live in their own homes (and pay rent). A normalisation has taken place which, however, can cause isolation, as in reality no significant social integration takes place, and the home, where different staff come and go and work efficiently, gets an institutionalised feel. As a reaction, today some of the old central institutions practise a 'village concept' where they turn the institution into a living environment (http://www. solund.dk/English.aspx).

\section{Care and control}

The last tension field to be mentioned here is the one between care and control. The aim with pedagogical actions is always to serve the other person's best interest - but what is the other person's best interest? And what if you are in doubt about whether or not the other person is aware of what is in his best interest? Are we then allowed to force him into what is in his best interest? The modern pedagogy is founded on the basis of the idea that independence and authority are the goals of pedagogy and that through the use of force one cannot bring anyone to freedom. The example above about dementia care was also about this tension field, and as the ideal pedagogical handling of the tension field we pointed toward the relationship and toward meaning. As a rule, the starting point for any pedagogical intervention is a relationship where you as a pedagogue can get a better understanding of the other person. This may result in a relationship which will also be perceived by the other person as valuable. By seeing the other person's individuality and by offering community, the other person also may become more motivated to seek a common meaning with the pedagogue. There is always the possibility of conflict, different wills and different opinions, but when there is a relationship and when the participants in this relationship experience that they are respected and their feelings and thoughts matter, there is a better chance for solving differences and disagreements and for finding a modus vivendi, a mutually acceptable way forward. 


\section{Challenges}

The tension fields refer to each other and together they indicate that social pedagogy is an unfinished job (Jensen, 2011) which is always performed on an imperfect foundation. Therefore, social pedagogical work is a work in progress which is supported by an inquiring approach. Any social pedagogical service should therefore contain research and development. Even though this is far from always the case, the social pedagogue should be inquiring and keep an open dialogue going with colleagues and citizens. In this dialogue, among other words, they use the words we have used to describe the tension fields.

In this respect, there lies a challenge in the very nature of the social pedagogical work. An externally induced challenge is that there are two more or less opposing tendencies that apply to the social pedagogical work in Denmark. The value orientation, which was clearly stated in the Consolidation Act on Social Services from 1998, is supported by international conventions, but at the same time there are competing demands that work with children, adolescents, disabled, addicts and others must be efficient, documentable and lead to them becoming employable. The last tendency is described in the context of the transition from welfare state to competitive state (Pedersen, 2013). While there are different and competing value orientations in modern pedagogical work, there is also an increasing expectation that the work is knowledge- and research-based. Now, our profession has a lot of knowledge about different circumstances which could be relevant, and to be well-informed is a good thing when you have to make decisions and choices. While some would settle for this 'informed choice', others would go further. They expect social pedagogy to be based on methods that work. This perspective is supported by the National Board of Health and Welfare. In the years 2012-15, implementation of programmes with evidence, such as Multi Systemic Therapy (MST), Parent Management Training Oregon (PMTO) and MultifunC was supported by 'Metodeudbredelsesprogrammet'6 run by the National Board of Health and Welfare with an annual budget of $€ 1.34$ million.

Jensen and Kjeldsen (2014) deal with what they call the schism between evidence-based practice, professional ethics and managerialism':

Politicians, municipalities and almost everybody else want the efforts documented, aiming at establishing a practice which is led by recognized and efficient methods. Such demands seem to 
forget a classic insight of social pedagogy, namely the distinction between 'verstehen' (understanding) and 'erklären' (explaining). Based on this distinction we find a continuous issue in the practical context. Social pedagogy is not necessarily bound to nomothetic laws; in fact it seems much more in accordance with an ideographic understanding in which each particularity is addressed with a similar particular practice. The scientific benefit of social pedagogical research and practice is thus drawing on an understanding of user/client, context and goal (Alexander, 1988, in Jensen \& Kjeldsen, 2014, p. 31).

Also the educational philosopher Gert Biesta $(2007,2010)$ argues that 'what works won't work in educational settings'.

Supporters of programmes with evidence, including the National Board of Health and Welfare, claim that these programmes provide transparency in both the content of social pedagogical work and on how resources are spent in relation to this work. In a social pedagogical perspective, one could argue that the programmes provide transparency on parts of the social pedagogical work. They offer structure, time, supervision, methodological ideas and short-term aims, all valuable aspects of social pedagogy.

On the other hand, we would argue that there seems to be a lack of transparency in several areas such as (1) in the long-term aims for the citizens who engage in the programmes, (2) in the underlying view of humanity, (3) in the understanding of power (structural and in the relationship between the social pedagogue and the young person/ child/citizen) and (4) on how the behaviouristic theory base fails to identify any significant cultural aspects of the countries of origin and differs from what we could here name as a traditional continental approach.

In relation to the tension fields mentioned earlier in the article, there is a risk that the 'evidence-based' programmes somehow install a false sense of security for social pedagogical practice. As described earlier, the evidence-based programmes claim to work and in some manuals, detailed actions are pointed out as having certain effects when it comes to promoting preferred behaviour. Prompting is an example of this. In the Norwegian manual developed in relation to the 30-session programme Aggression Replacement Training (Gundersen et al., 2008) it is stated by the authors that giving the participants diplomas, small gifts, etc. will enforce pro-social behaviour. For instance it is suggested how little cards, with a short description of what the individual young 
person is doing well, like 'You have become really good at waiting for your turn', can be written beforehand and then handed out in the exact moment that the young person actually waits for his/her turn, emphasising the behaviouristic learning-principles and ignoring the negative side effects of generalised rewards (see Kohn, 1999). We argue that yet another tension field could be emerging here: the one between manualised programmes and the professional, well-reflected social pedagogue. Dangers/risks include that the social pedagogue could end up looking for and acknowledging only the pro-social behaviour as defined by the programme and by the social pedagogue in situ, potentially failing to recognise the young person as an individual with a full identity and teaching compliance rather than inspiring intrinsic motivation. One way to handle the suggested tension could be to allow the manual to inform as opposed to form practice, employing at the same time a constantly developing awareness of how practice develops and where the young person seems to be in his/her life.

The following situation from an Aggression Replacement Training course for three young men provides us with an example of this:

We are six weeks into the ten-week-long programme. The young men have had some trouble attending the programme during the first weeks, due to all sorts of obstacles: they failed to get up in the morning, they forgot about the course or they met other young people on their way to school who wanted them to go elsewhere. At this point, six weeks into the programme, they are actually succeeding in showing up to most of the sessions. The manual suggests, as described above, to use the cards as prompts for pro-social behavior. As ART-trainer and social pedagogue I wish to show the young men just how much I appreciate their effort to attend the programme. So, instead of pointing out which behaviour I wish to see more of, I write a card for each of the young men, describing how I would like to recognise their participation and how I see and understand their contribution to our sessions together. From the way they each opened their envelopes, read the card and carefully put it back in the envelope and then in their pockets - without discussing the cards between them, it seemed to me that they received the cards in the spirit they were given, as a sign of recognition. My fear would have been that the cards had meant nothing to them or, even worse that the cards would have come across as an instrument to motivate the young men to behave in a certain way. 
We argue that a way of balancing social pedagogical professionalism and evidence-based method-orientation is the use of programmes and methods as inspiration, ${ }^{7}$ not as knowledge. Knowing that certain interventions have been successful in relation to certain goals in specific settings can inform the choices the professional makes in relation to his or her own practice. A well-reflected social pedagogical practice is characterised by informed choices, taking into consideration that intersubjectivity, mutual understanding and recognition and attention to the tensions mentioned above are cornerstones for the development of personal integrity, social integration and participation.

\section{Notes}

1 Reform pedagogy was originally also a German movement. It is often translated as 'progressive education' in English.

2 Even though the intention was to treat the youngsters as participants, there was also often a very disciplinary socialisation in the specific community: on the ship, obedience was required and at the former farmhouse a kind of Makarenkoinspired pedagogy was rooted in the adults knowing best what non-bourgeois behaviour and opinions were considered acceptable.

3 When social pedagogy had become the underpinning approach for care practice in 24-hour institutions in the 1970s, it was inspired by different psychological and sociological theories that disregarded the child's unique self and instead urged the pedagogues to create an idealised version of the child, whether it was a child with 'ego-strength' or 'the socialistic human being'. The theoretical ideal 'let' the pedagogues decide over the child, to 'give it an outer structure' which the child subsequently could turn into 'an inner structure'. Tuft (2009) calls it 'the narrow perception of social pedagogy' and sees it as a totalitarian tendency that is always lurking (also see Schwartz, 2000). Biesta and Säfstrøm's Manifesto for education (Biesta and Säfstrøm 2011) is an actual description of the theory-practice relationship which makes the practitioner responsible for the mediation between theory and practice.

4 When Mr. Hansen was called 'a shouter' the shouting was interpreted as a typical symptom of his dementia, and as long as the behaviour is interpreted as a symptom the remedy is medicine, e.g. a tranquilliser.

5 Ovartaci's story has been described and his works can be seen in the museum in the psychiatric hospital and on http:// ovartaci.dk/eng/kunstnere/ovartaci_eng. htm

6 Directly translated into English this would be "The programme aiming to spread methods/programs with evidence'.

7 As suggested by the authors (Gundersen et al., 2008, p. 6).

\section{References}

Alexander, J. C. (1988). The new theoretical movement. In N. Smelser (ed.), Handbook of Sociology (pp. 77-101). London: Sage.

Aude, J., and Bundesen, P. (2003). De kollektive børne- og ungdomsmiljøer: fra alternativ til fornyere. In J. Seemann \& T. Ussing Bømler (eds), 
Mod strømmen - Tore Jacob Hegland in memoriam. Aalborg: Aalborg Universitets Forlag.

Banks, S., \& Nøhr, K. (eds) (2003). Teaching Practical Ethics for the Social Professions. Copenhagen: FESET. http://www.feset.org/fileadmin/ content/ESEP/Teaching_practical_ethics.PDF

Bengtsson, S., Storgaard Bonfils, I., \& Olsen, L. (eds) (2003). Handicap, kvalitetsudvikling og brugerindragelse. Copenhagen: AKF forlag. http:// tinyurl.com/bxyydb6

Biesta, G. (2007). Why 'what works' won't work: Evidence-based practice and the democratic deficit in educational research. Educational Theory, 57(1), 1-22 .

Biesta, G. (2010). Why 'what works' still won't work: From evidence-based education to value-based education. Studies in Philosophy and Education, 29(5), 491-503.

Biesta, G. (2012). The educational significance of the experience of resistance: Schooling and the dialogue between child and world. Other Education: The Journal of Educational Alternatives, 1(1), 92-103.

Biesta, G., \& Säfstrøm, C. A. (2011). A manifesto for education. Policy Futures in Education, 9(5), 540-7. DOI: http://dx.doi.org/10.2304/ pfie.2011.9.5.540

Bondi, L., Carr, D., Clark, C., \& Clegg, C. (2011). Towards Professional Wisdom: Practical Deliberation in the People Professions. Farnham: Ashgate. Durkheim, E. (1957). Professional Ethics and Civic Morals (pp. 1-13). London: Routledge.

Dybro, L. (ed.) (2009). Øen I søen: Fortællingerom demensomsorg. Odense: Servicestyrelsen.

Eichsteller, G. (2009). Janusz Korczak: His legacy and its relevance for children's rights today. International Journal of Children's Rights, 17, 377-91.

Eichsteller, G., \& Holthoff, S. (2011). Social pedagogy as an ethical orientation towards working with people: Historical perspectives. Children Australia, 36, 176-86.

Erlandsen, T. (2006). Hvem navngav 'socialpædagogerne' i Danmark? Dansk Tidsskrift for Socialpædagogik, 17, 45-52.

Erlandsen, T., \& Kornbeck, J. (2004). Die deutschstämmige Sozialpädagogik in Dänemark. Einbürgerung und Nostrifizierung (1901-1940). Jahrbuch für historische Bildungsforschung, 10, S193-S216.

Erstad, I. (2008). Description of the knowledgeing workshop as a model in upgrade and further education: Method and process. http://tinyurl.com/ sesproject; http://tinyurl.com/sesproject2

Foucault, M. (1995) [1975]. Discipline and Punish: The Birth of the Prison. New York: Vintage. 
Gofman, Erving (1961). Asylums: Essays on the Social Situation of Mental Patients and Other Inmates. New York: Doubleday.

Gundersen, K., Olsen, T., \& Finne, J. (2008). ART: En metode for trening af sosial kompetanse. Rogaland, Sandnes: Diakonhjemmet Høgskole.

Hämäläinen, J. (2012) Social pedagogical eyes in the midst of diverse understandings, conceptualisations and activities. International Journal of Social Pedagogy, 1(1), 3-16.

Hegland, T. J. (1994) The Socially Excluded. Aalborg: Aalborg Universitetsforlag,

Honneth, A. 1996. The Struggle for Recognition: The Moral Grammar of Social Conflicts. Cambridge, Mass.: MIT Press.

Jensen, M. (2011). Det ufærdige arbejde: Udvikling og vurdering af kvaliteten af socialpædagogisk arbejde. En hermeneutisk udforskning af socialpædagogisk arbejde på døgninstitutioner med henblik på at udvikle forståelser af de psykiske processer heri for derved at kunne kvalificere det yderligere og evaluere kvaliteten af det. Aalborg: Aalborg Universitet. http://tinyurl. com/amwcd4e

Jensen, N. R., \& Kjeldsen, C. C. (2014). T: The schism between evidencebased practice, professional ethics and managerialism - exemplified by social pedagogy. Cursiv (November), http://edu.au.dk/forskning/publi kationer/cursivskriftserie/

Kohn, A. (1999). Punished by Rewards. Boston, Mass.: Houghton Mifflin Co.

Konrad, F. M. (2009). Fragile Professionalisierungen: Zur geisteswissenschaftlichen Sozialpädagogik, ihre Vorgeschichte und ihren Widerspiegelungen bis heute. In E. Mührel \& B. Birgmeier (eds), Theorien der Sozialpädagogik - ein Theorie-Dilemma? (pp. 99-128). Wiesbaden: VS/GWF.

Kornbeck, J., \& Rosendahl Jensen, N. (eds) (2011). Social Pedagogy for the Entire Lifespan (vol. 1). Bremen: EH Verlag.

Langager, S. (2009). Social pedagogy and at-risk youth: Societal changes and new challenges in social work with youth. In J. Kornbeck \& N. Rosendahl Jensen (eds), The Diversity of Social Pedagogy in Europe (pp. 83-105). Bremen: Europäischer Hochschulverlag.

Mors, N. (2008). Fortællinger på arbejde. In S. Idun and N. Mors (eds), Pædagogiske praksisfortællinger (pp. 43-66). Århus: Academica.

Moss, P. (2007). Starting strong: An exercise in international learning. International Journal of Child Care and Education Policy, 1(1), $11-21$.

OECD (2001). Starting Strong: Early Childhood Education and Care. Paris: OECD Publications. 
OECD (2006). Starting Strong II: Early Childhood Education and Care. Paris: OECD Publications.

Ofman, D. (2001). Core Qualities: A Gateway to Human Resources. Schiedam: Scriptum.

Pedersen, O. K. (2013). 'The Competition State', in Benedikte Brincker (ed.), Introduction to Political Sociology (pp. 281-98). Copenhagen: Hans Reitzels Forlag.

Regional Youth Work Unit North East (2010) A Study on the Understanding of Social Pedagogy and its Potential Implications for Youth Work Practice and Training. Sunderland: University of Sunderland. http://tinyurl.com/ b3njjwx

Rothuizen, J. J. (2008). Quality Assurance in Social Work Practice: Qualification of Knowledge in Action. http://tinyurl.com/benxx9z

Rothuizen, J. J. (2013). Socialpædagogisk udviklingsarbejde. In T. Erlandsen et al. (eds), Grundbog i socialpædagogik (pp. 268-81). Copenhagen: Hans Reitzel.

Schwartz, I. (2000) 'Indre kaos hos børn kræver ydre styring' -eller gør det? Social Kritik, 70, 58-73.

Shepherd, G., Boardman, J., \& Slate, M. (2008). Making Recovery a Reality. London: Sainsbury Centre for Mental Health. http://tinyurl. com/338muy8

Slade, M., \& Longden, E. (2015). The empirical evidence about mental health and recovery: how likely, how long, what helps? Victoria: MI Fellowship.

Swinton, J. (2011). The wisdom of L'Arche and the practices of care: Disability, professional wisdom and encounter-in-community. In L. Bondi et al. (eds), Towards Professional Wisdom: Practical Deliberation in the People Professions (pp. 153-68). Farnham: Ashgate.

Tuft, K. (2009). Socialpædagogik. In N. Mors \& S. I. Mørch (eds), Pædagog $i$ en mangfoldig verden: Profession, udvikling, forskning (pp. 43-58). Viborg: Academia.

United Nations (2006). Convention on the Rights of Persons with Disabilities. http://www.un.org/disabilities/default.asp? navid $=14 \&$ pid $=150$ 